\title{
Autonomic Nervous System and Allergic Diseases: Integrative Literature Review
}

Elisangela Vilar de Assis', Ubiraídys de Andrade Isidório², Ankilma do Nascimento Andrade Feitosa², Milena Nunes Alves de Sousa2, Gylmara Bezerra de Menezes Silveira1, Hermes Melo Teixeira Batista1, Italla Maria Pinheiro Bezerra1, Vitor Engrácia Valenti ${ }^{3}$, Luiz Carlos de Abreu ${ }^{1}$

\section{Abstract}

Introduction: Allergic diseases have their incidence constantly increased especially asthma, allergic rhinitis and eczema or atopic dermatitis. The causes related with the appearance of these diseases such as the environment, hereditary and others are unable to explain certain behaviors. Changes in the autonomic nervous system (ANS) are cited as one of the factors that may contribute to the onset of exacerbations.

Objective: Identify the autonomic nervous system's behavior in allergic diseases.

Methods: Integrative literature review conducted from the following databases: Scielo, Lilacs and PubMed. The keywords used were autonomic nervous system, asthma, allergic rhinitis and eczema in Portuguese, English and Spanish languages. Four articles were selected for this review.

Results: The selected articles point to an increased activity of the parasympathetic nervous system or decreased activity of the sympathetic system in cases of allergic rhinitis. With asthma, it is believed that the changes in the ANS are secondary to diseases. Articles about atopic eczema were not found using the selected words to search.

Conclusion: There is evidence of changes in the ANS in allergic diseases, however, there is so far no study that states which system
1 University of Medicine $A B C$, Santo André, SP, Brazil..

2 University Santa Maria, Cajazeiras, PB, Brazil.

3 Post-Graduation Program in Physiotherapy, University of Science and Technology, UNESP, Presidente Prudente, SP, Brazil.

\section{Contact information:}

\section{Luiz Carlos de Abreu.}

Laboratório de Delineamento de Estudos e Escrita Científica. Departamento de Saúde da Coletividade. Disciplina de Metodologia Científica.

Address: Faculdade de Medicina do ABC. Santo André, SP. Brasil. Av. Príncipe de Gales, 821, Santo André, SP CEP 09060 650.

\section{झLuiz.abreu@gmail.com}


excels, only that the parasympathetic is more active or that the sympathetic is in underactivity.

\section{Keywords}

Autonomic nervous system; Asthma; Allergic rhinitis; Atopic eczema.

\section{Introduction}

The allergy is caused by allergens or antigens that are typically foreign proteins that can be pollen, animal hair or dander, food, cockroach droppings and mold spores. The development of allergic disease in different organs can affect the same person. Some studies have shown a positive association between allergic rhinitis, asthma, atopic dermatitis, allergic conjunctivitis and food allergies [1].

National and international consensus suggest that environmental control should be performed as part of the treatment for allergic diseases, especiaIly asthma and allergic rhinitis, as the contact with allergens would contribute to the inflammation present in these diseases [2].

The association between allergic diseases is quite common, especially among the correlation between allergic rhinitis (AR), atopic dermatitis and asthma. It is estimated that $38 \%$ of patients with AR have asthma and $78 \%$ of asthmatics also have rhinitis. Some studies suggest that AR and asthma have the same pathophysiological mechanism, since the treatment of $A R$ contributes to reducing the incidence and severity of asthma. With regards to atopic dermatitis, despite having a good prognosis, it is constantly related to the appearance of signs and symptoms of AR and asthma [3].

Allergic rhinitis is a public health problem because it causes an economic and social impact in the community, affecting the patient's quality of life through physical and emotional discomfort. It is a disease of high prevalence and according to the International Study of Asthma and Allergies in Childhood (ISAAC) conducted in the late 90s the association between asthma and allergic rhinitis can reach up to $80 \%$ [4].

Many disorders that arise in humans are related to changes in the autonomic nervous system, including allergic diseases. In the atopic disorders the sympathetic activity is decreased in all body tissues, except at sites of allergic reaction. Studies have shown that patients with atopic dermatitis and allergic rhinitis who have reduction of sympathetic tone may have association with the severity of the disease [5].

The autonomic nervous system is responsible for homeostasis. It innervates the cardiac muscle, smooth muscle and multiple endocrine and exocrine glands, affecting the activity of most tissues and systems of our body [6].

Thus, the objective of this review is to describe the behavior of the autonomic nervous system in allergic diseases.

\section{Methods}

This research is of a type called integrative literature review that guides the review process through six steps. The $1^{\text {st }}$ step is the issue identification and selection of the research question. The $2^{\text {nd }}$ step is the establishment of inclusion and exclusion criteria. The $3^{\text {rd }}$ step is the identification of pre-selected and selected studies, in addition to careful reading of the titles, abstracts and keywords of all comple- 
te publications found by the search strategy. The $4^{\text {th }}$ step is the categorization of the selected studies which is carried out through the summary and documentation of the information obtained from scientific articles found. The $5^{\text {th }}$ step is the analysis and interpretation of the results. The $6^{\text {th }}$ step is the presentation of the synthesis of knowledge [7] (figure 1). After the selection process only four articles that followed the inclusion criteria were found for this review.

The selection of the articles occurred during the months of August and September 2014 through a combination of the terms: "autonomic nervous system", "asthma", "allergic rhinitis" and "atopic eczema" in the databases: Literatura Latino-Americana e do Caribe em Ciências da Saúde (Lilacs), Scientific Electronic Library Online (SciELO) and PubMed. The terms were used in Portuguese, English and Spanish (Table 1).
Table 1. Number of articles found by database and keywords.

\begin{tabular}{|l|l|c|}
\hline Database & \multicolumn{1}{|c|}{ Keywords } & No of articles \\
\hline \multirow{4}{*}{ Pubmed } & Autonomic Nervous System & 140.607 \\
\cline { 2 - 3 } & ANS AND Allergic rhinitis & 107 \\
& ANS AND Asthma & 901 \\
\cline { 2 - 3 } & ANS AND Atopic Eczema & 47 \\
\hline \multirow{4}{*}{ Scielo } & Autonomic Nervous System & 57 \\
& ANS AND Allergic rhinitis & 0 \\
\hline \multirow{5}{*}{ Lilacs } & ANS AND Asthma & 0 \\
\hline & ANS AND Atopic Eczema & 0 \\
\hline & Autonomic Nervous System & 491 \\
\hline & ANS AND Allergic rhinitis & 0 \\
\hline & ANS AND Asthma & 02 \\
\hline & ANS AND Atopic Eczema & 01 \\
\hline
\end{tabular}

Figure 1: Flowchart of number of articles found and selected after applying the inclusion and exclusion criteria.

Articles excluded after their complete reading $(n=02)$
Articles found by the search strategy:

PubMed = 141.805; Lilacs $=494 ;$ Scielo $=57$;

$(n=142.356)$

\section{Articles excluded after \\ title reading \\ $(n=142.337)$}

Articles included after title reading $(n=19)$

Articles excluded after reading the abstract $(n=13)$

Articles selected after reading the abstract $(n=06)$
Repeated articles $(n=0)$

Articles to be analyzed for this review

$$
(n=04)
$$


The following inclusion criteria were used: original articles, articles of intervention, quasi-experimental, randomized and cross-sectional studies published between 2004 and 2014 with free access, presenting in the title at least one of the terms used for the search. Abstracts, dissertations, theses and review articles were excluded.

\section{Results}

A summary of the results related to the action of the autonomic nervous system in allergic diseases can be found in table 2 .

\section{Discussion}

In recent decades the increasing prevalence of allergies and asthma among children and adults has become constant. There is growing evidences that these diseases arise very early, even in intrauterine stage contributing to atopic diseases [11]. Emin et al [5] differently from what was observed in their studies believe that in allergic diseases the sympathetic and parasympathetic systems are not affected simultaneously but one of them may be involved in a predominantly or exclusively form.

Among the factors that are associated with the incidence of allergic diseases, Kristine et al. [11] point out that clinical studies have suggested that com-

Table 2. Impacts from the perspective of death in pediatric oncology patients. Main consideration of the authors.

\begin{tabular}{|c|c|c|c|}
\hline Authors & Sample size (N) & Results & News \\
\hline $\begin{array}{l}\text { Emin et } \\
\text { al. [5], } \\
2012\end{array}$ & $\begin{array}{l}\text { Fifty six children aged between } \\
6-11 \text { years old with allergic rhinitis. }\end{array}$ & $\begin{array}{l}\text { Children with allergic rhinitis have a } \\
\text { hyperactivity of the parasympathetic } \\
\text { nervous system or imbalance between } \\
\text { the parasympathetic and sympathetic } \\
\text { system, with a sympathetic hypoactivity. } \\
\text { The sympathetic activity is related to the } \\
\text { severity of allergic rhinitis. }\end{array}$ & $\begin{array}{l}\text { It is speculated that the } \\
\text { dysfunction of the ANS activity } \\
\text { can be one of the causes that } \\
\text { contribute to the development of } \\
\text { the disease's severity in children } \\
\text { with allergic rhinitis. }\end{array}$ \\
\hline $\begin{array}{l}\text { Lan et } \\
\text { al. [8], } \\
2013\end{array}$ & $\begin{array}{l}\text { The average age of the group } \\
\text { with allergic rhinitis ( } 7 \text { men and } \\
4 \text { women) was } 29.5 \text { years old } \\
\text { (ranging between } 22-40 \text { years old). } \\
\text { The average age of the control } \\
\text { group ( } 5 \text { men and } 8 \text { women) was } \\
29.77 \text { years old (ranging between } \\
19-29 \text { years old). }\end{array}$ & $\begin{array}{l}\text { Participants with allergic rhinitis have } \\
\text { a bad sympathetic modulation when } \\
\text { compared to the control group. }\end{array}$ & $\begin{array}{l}\text { The autonomic dysfunction may } \\
\text { be involved in the allergic rhinitis's } \\
\text { pathophysiology }\end{array}$ \\
\hline $\begin{array}{l}\text { Emin et } \\
\text { al. [9], } \\
2012\end{array}$ & $\begin{array}{l}77 \text { children ( } 46 \text { boys, } 31 \text { girls } \\
\text { aged between } 7-12 \text { years old) } \\
\text { who had recently been diagnosed } \\
\text { with asthma without other } \\
\text { comorbidities. }\end{array}$ & $\begin{array}{l}\text { In tests of heart rate variability (HRV) } \\
\text { and heart rate response to deep } \\
\text { breathing (HRDB), two parameters } \\
\text { related to primary dysfunction of the } \\
\text { PN were correlated to the severity of } \\
\text { asthma symptoms. }\end{array}$ & $\begin{array}{l}\text { Asthmatic children the parameters } \\
\text { of the autonomic nervous system } \\
\text { were positively correlated with } \\
\text { the severity of atopic asthma and } \\
\text { asthmatic children even out of } \\
\text { the crisis show changes in the } \\
\text { ANS when compared to children } \\
\text { without asthma. }\end{array}$ \\
\hline $\begin{array}{c}\text { Kumar et } \\
\text { al. [10], } \\
2012\end{array}$ & $\begin{array}{l}60 \text { children ( } 5 \text { to } 10 \text { years old) } \\
\text { divided into two groups: test } \\
\text { group with } 30 \text { healthy children } \\
\text { of parents with asthma. Control } \\
\text { group within the same age group } \\
\text { with } 30 \text { healthy children of non- } \\
\text { asthmatic parents. }\end{array}$ & $\begin{array}{l}\text { The research did not observe changes } \\
\text { in analyzed variables that could suggest } \\
\text { the presence of autonomic dysfunction } \\
\text { in children of asthmatic parents. }\end{array}$ & $\begin{array}{l}\text { The autonomic modifications } \\
\text { present in asthma arise as a result } \\
\text { of secondary changes to the } \\
\text { disease process. }\end{array}$ \\
\hline
\end{tabular}


plications during pregnancy may increase the risk of children presenting asthma and allergic rhinoconjunctivitis in childhood, and that an association between maternal preeclampsia with a subsequent allergic sensitization has been suggested during adolescence.

Allergic rhinitis as well as other atopic diseases is part of a complex of systemic diseases and only inflammation is not sufficient to explain its chronicity. It is believed that it is a multifactorial disease and the neurological component has an important role for its appearance [5].

The symptoms of rhinitis are related to neural activity that is influenced by inflammation, but it is possible that the neural function produces interactions with the immune system, which can enhance or suppress inflammation. This relationship is insufficiently studied, although the evidence indicates its importance in rhinitis. The nervous system, which makes the connection between the nose and other parts of the respiratory tract, may also make this connection between other organs. Thus, events that begin in the nasal airways can send a stimulus to other organs and vice versa, leading to the appearance of complex clinical manifestations in the pathological process [12].

In studies from Ozsutcu et al. [13] it was observed an increase of vagal activity through pupillometry, showing that the constriction of the pupil size in response to a light stimulation in children with allergic rhinitis may indicate parasympathetic hyperactivity.

Longitudinal studies suggest that rhinitis precedes asthma and that it is an important marker of severity for it, in addition it makes the control of asthma difficult and raises the cost of its treatment. Studies show that there is a predominance of asthma and rhinitis symptoms in females during adolescence and that several factors are related to this event, such as: smaller airway caliber, hormonal factors and greater exposure to sex specific allergens [14].

In the case of asthma, a parasympathetic nervous system (PN) hyperfunction can occur in the airway or an imbalance between parasympathetic nervous system (PN) and the sympathetic nervous system (SNS). The theory that the PN's dysfunction is associated with asthma is based on clinical observations and experimental searches9. For Kumar et al. (2012) the autonomic changes presented in asthma do not have a hereditary character but a secondary relation to the development of the disease. [10]

Emin et al.[9] suggest that asthmatic children even out of the crisis show changes in the functions of the autonomic nervous system and that these changes associated with dysfunction of the parasympathetic nervous system rather than a sympathetic hypoactivity may be related to the severity of asthma.

In studies from Ciceck et al.[15] the action of the median nerve by means of an electromyography was evaluated in 38 atopic dermatitis patients (24 with active disease and 14 inactive) and the control group with 10 participants. The functions of the autonomic nervous system were studied by the R-R interval variation (RRIV), representing the parasympathetic nervous system and the sympathetic skin response (SSR). There were no statistical differences regarding the sympathetic response among the group of active and non-active dermatitis as well as between the non-active and the control group. It was also observed there were no changes in parasympathetic response in the atopic dermatitis group.

The allergic diseases are linked to abnormalities of the autonomic nervous system that plays an important role in the symptomatology of hypersensitivity reactions, however, the mechanism by which these events take place are not very clear [13], it is known that after the performance of surgical and pharmacological denervation of the parasympathetic nerves the onset of the disease is prevented as well as its manifestations and progressions [1].

Through this review it can be seen that allergic diseases are related to changes in the autonomic nervous system (ANS), but that these changes are not necessarily responsible for the appearance of these diseases, emerging when a stressor factor tri- 
ggers the crisis. Future studies that follow people who are affected by allergic diseases over a longer period of time are needed so that we can identify the actual ANS's behavior before, during and after the appearance of crisis, as well as investigate if the hereditary factor presents a major impact for the appearance of this autonomic dysfunction.

\section{References}

1. Scotta GD, Fryera AD. Role of Parasympathetic Nerves and Muscarinic Receptors in Allergy and Asthma. Chem/mmunol Allergy. 2012; 98: 48-69

2. Castro TMPPG, Marinho DRT, Cavalcante CC. The impact of environmental factors on quality of life and symptoms of children with allergic rhinitis. Braz J Otorhinolaryngol. 2013; 79(5): 569-74

3. Camelo-Nunes IC, Solé D. Rinite alérgica: indicadores de qualidade de vida. J BrasPneumol. 2010; 36(1): 124-133.

5. Emin O, Esra G, Ufuk E, Demiric A, Ayhan S, Rusen D M. Autonomic dysfunction and clinical severity of disease in children withallergic rhinitis. International Journal of Pediatric Otorhinolaryngology 2012; 76: 1196-1200.

4. Menezes VA, Barbosa AMF, Souza RMS, Freire CVC, GranvilleGarcia AF. Ocorrência de rinite, respiração oral e alterações orofaciais em adolescentes asmáticos. Rev. CEFAC. 2013; 15(3): 663-671.

6. McCorry LK, College BS. Physiology of the Autonomic Nervous System. American Journal of Pharmaceutical Education 2007; 71 (4) Article 78.

7. Duarte KM et al. Importância da Fisioterapia na Estratégia Saúde da Família: revisão integrativa. Revista de Enfermagem UEPE online. 2013; 7(12): 321-7.

8. Lan Ming-Ying, Lee Guo-She, Shiao An-Suey, Ko Jen-Hung, ShuChih-Hung. Heart Rate Variability Analysis in Patients with Allergic Rhinitis. The ScientificWorld Journal.2013: 1-5

9. Emin O, Esra G, Aysegul D, Ufuk E, Ayhan S, Rusen D M. Autonomic nervous system dysfunction and their relationship with diseaseseverity in children with atopic asthma. Respiratory Physiology \& Neurobiology 2012; 183: 206- 210

10. Kumar S, Babbar R, Varshney V P, Daga M K, Dalvi V S. A study of autonomic nervous system status in childrenof asthmatic parents. Indian J PhysiolPharmacollndian J PhysiolPharmacol 2012; 56(1): 74-79.

11. Byberg KK, Ogland B, Eide GE, Oymar K. Birth after preeclamptic pregnancies: association with allergic sensitization and allergic rhinoconjunctivitis in late childhood; a historically matched cohort study. BMC Pediatrics. 2014; 14: 1-8.
12. Sarin S, Undem B, Sanico A, Togias A. The role of the nervous system in rhinitis. J Allergy Clinlmmunol. 2006; 118(5): 9991014.

13. Ozsutcu M, Ozkaya E, Demir A, Erenberk U, Sogut A, Dundaroz R. Pupillometric Assessment of Autonomic Nervous System in Children with Allergic Rhinitis. MedPrincPract. 2013; 22: 444448

14. Luna MFG, Almeida PC, Silva MGC. Prevalência e associação de asma e rinite em adolescentes de 13 e 14 anos de Fortaleza, Ceará, Brasil. Cad. Saúde Pública. 2011; 27(1): 103-112.

15. Cicek D, Kandi B, Berilgen MS, Bulut S, Tekatas A, Dertlioglu SB et al. Does autonomic dysfunction play a role in atopic dermatitis? British Journal of Dermatology. 2008; 159: 834-838.

\section{Comment on this article:}

\section{7 (in $8+\mathcal{S} P$}

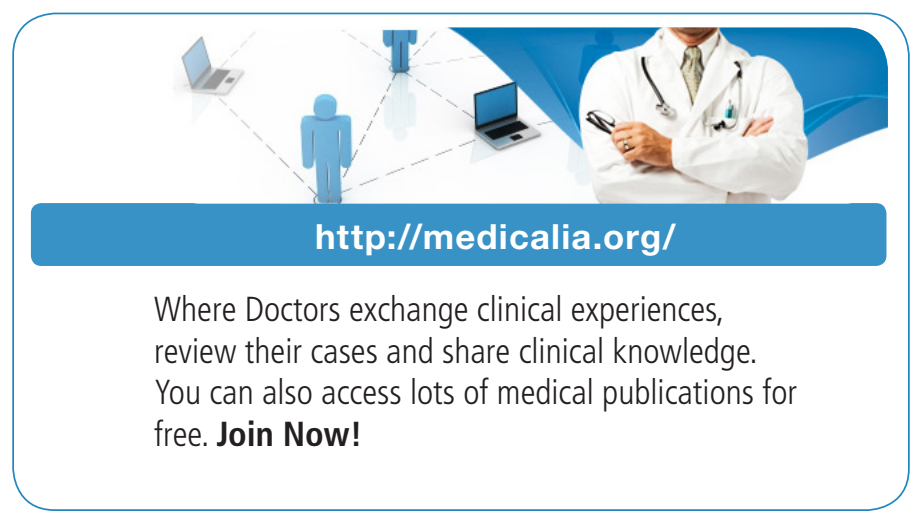

\section{Publish with iMedPub}

\section{http://www.imed.pub}

International Archives of Medicine is an open access journal publishing articles encompassing all aspects of medical science and clinical practice. IAM is considered a megajournal with independent sections on all areas of medicine. IAM is a really international journal with authors and board members from all around the world. The journal is widely indexed and classified Q1 in category Medicine. 